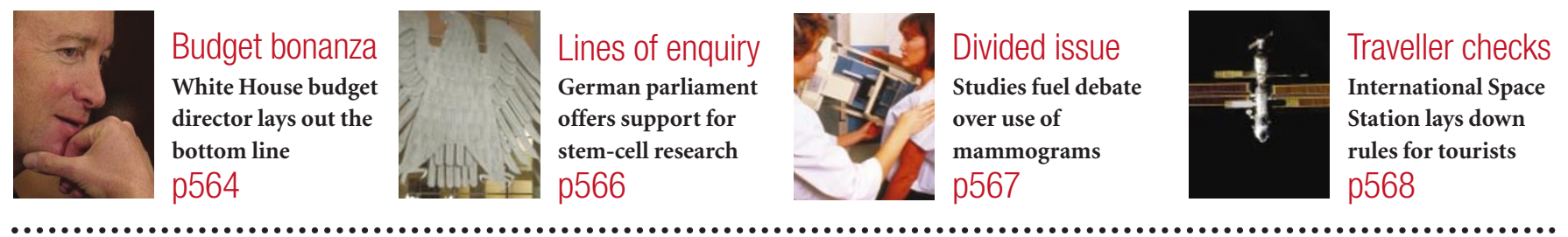

\title{
National audit slams CNRS over poor management and planning
}

\section{Sally Goodman, Paris}

France's largest and most prestigious research agency, the CNRS, has been severely criticized in a national audit for its alleged lack of strategic planning, weak financial management and flawed humanresources policy.

The audit says that the agency's cumbersome 800-member national committee, and the high degree of autonomy enjoyed by its 1,200 laboratories, prevent it from planning properly.

The criticisms are likely to lead to a major overhaul of the research agency and its governing committee - although the CNRS says that many of them are already being addressed in a new strategic plan that it will endorse this month.

The ability of researchers to move within the CNRS and to conduct interdisciplinary research is stifled, the audit says, by the inflexibility of the agency's discipline-based organization and evaluation system. The audit also charges that the CNRS - whose budget of 2.4 billion euros (US $\$ 2.1$ billion) makes it the largest supporter of basic scientific research in Europe - is not taking a leadership role in research involving other European countries.

The audit also criticizes the financial management of the agency, pointing out that its laboratories consistently underspend their allocated budgets, holding back the money for a rainy day. It adds that the agency faces a recruitment crisis, with half of its staff due to retire by 2020.

Despite recent reforms at the administrative level (see Nature 404, 426; 2000), the auditors charge that the CNRS and its parent research ministry have been "incapable of getting beyond the stage of collective reflection and group discussions" in enacting reform.

The current management team Gérard Mégie, the agency's president, and Geneviève Berger, its director-general were appointed in 2000 to lead a new management structure at the agency.

"This is a key moment for the CNRS," says Mégie. "We have done the thinking: now we need to translate this into action."

The agency's strategic plan says it will give
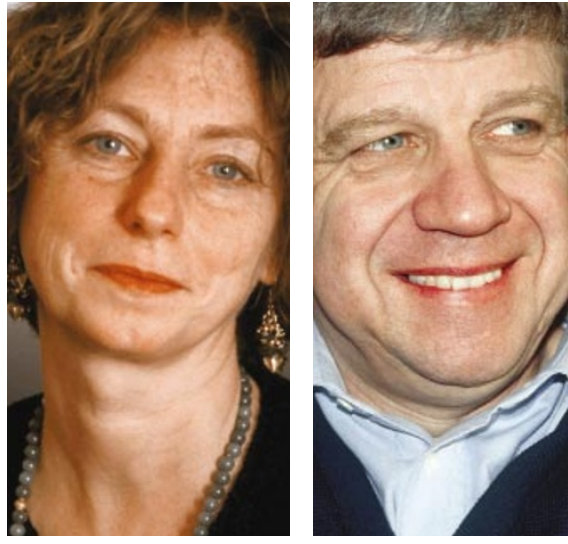

Under fire: Geneviève Berger (left) and Gérard Mégie say reforms at the CNRS are working.

priority to interdisciplinary work and to integration into the European Research Area. It introduces four-year contracts between CNRS management and its laboratories, defining their budgets, objectives and evaluation procedures. Mégie says that he hopes the changes "will encourage researchers to take risks in their careers".

A 1998 plan by former research minister Claude Allègre to reduce the influence of the agency's national committee was abandoned in the face of fierce opposition from researchers (see Nature 396, 607; 1998). Berger says that the agency's own plan will reform the committee in a manner "no less radical than Allègre's, but better prepared".

The ministry of research, which itself is implicitly criticized by the auditors, says that many reforms have been implemented since the audit started two years ago. A new 'contract of objectives' between the ministry and the CNRS will be signed next month, defining long- and short-term objectives for the agency. "The contract will contain a number of performance indicators" says Ketty Schwartz, research director at the ministry.

\section{Developing world gets patent aid}

Declan Butler, Paris

An international organization is to be set up later this year to help health researchers in the developing world to navigate the complex maze of intellectual-property law.

Patent and licensing agreements often have a bad name in developing countries. They are widely associated, for example, with the lack of affordable access to drug treatment for diseases such as AIDS.

The new body, called the Management of Intellectual Property in Health R\&D (MIHR), aims to assist governments in the developing world to negotiate better deals for drug access, as well as helping researchers there to protect their own ideas. The New York-based Rockefeller Foundation will provide start-up funding of US\$500,000 for the MIHR. With input from other donors, the MIHR's annual budget should reach US\$3 million by 2006 .

The organization will employ a small staff of patent lawyers to give training and free legal advice to governments and researchers in poor countries. It also plans to create freeaccess databases of patent information relevant to diseases such as malaria.

Ariel Pablos-Mendez, an associate director at the Rockefeller Foundation, says that the MIHR will try to persuade universities in rich nations to include provisions beneficial to poor countries in their licensing deals with drug companies.

John Kilama, president of the Global Biodiversity Institute, a Delaware-based organization providing information and training in biotechnology to developing countries, says that the MIHR can "fill a very important gap" by encouraging developing countries to make patent protection serve their own needs.

But Rosemary Wolson, an intellectualproperty consultant at the University of Cape Town in South Africa, warns that it will not be easy for the new organization to win credibility, "bearing in mind how politically fraught the relevant issues are". 